\title{
NARCOLEPSY IN IDENTICAL TWINS
}

\author{
BY
}

\author{
NORMAN W. IMLAH
}

From the Uffculme Clinic, Birmingham

Narcolepsy has been observed in chronic encephalitis, cerebral arteriosclerosis, brain tumour, and following trauma, but when these cases are excluded there remains a group without demonstrable brain pathology. The existence of this idiopathic group has been a controversial subject. Among the more impressive evidence is that suggesting a hereditary factor in idiopathic narcolepsy. To date this evidence has not contained an account of the condition in identical twins, and the existence of such a case is, therefore, reported.

The case came to our notice because one of a pair of twins was referred for psychiatric opinion.

The patient a man, aged 28, was admitted for full assessment and at the same time the twin brother was investigated. The monozygotic origin of the twins was shown by application of the similarity diagnosis (Stern, 1950). The following criteria of identicality were applied: (1) Striking similarity in general appearance, and (2) essential identity in (a) hair colour, (b) hair texture, (c) hair form, $(d)$ eye colour, $(e)$ skin colour, $(f)$ amount and distribution of body hair, $(g)$ features of nose, lips, chin, and ears, $(h)$ type and proportions of hands and fingers, $(i)$ height and weight.

In appearance both were $6 \mathrm{ft}$. in height, broadly built, black-haired, and sallow-complexioned. The hands and feet were large, and the jaws were overdeveloped giving a rather acromegaloid appearance to the face. The physical similarities were supported by repeated E.E.G. records which showed the basic similarities expected in identical twins.

Their father was interviewed for confirmation of family and early history. He was an ex-professional boxer, of good intelligence.

\section{Case Reports}

The family history of both parents was negative for narcolepsy, epilepsy, and mental defect; the twins were their sole offspring. The birth and development of the twins was normal. As children they had measles, whooping cough, and chickenpox without complications, and revealed nothing untoward until the appearance of symptoms of narcolepsy.
The Patient.-W. first experienced symptoms at the age of 13. These began with a tendency to fall asleep a school, particularly when he sat near radiators or in कै stuffy classroom. He found increasing difficulty in getting up in the morning, and after arousal remained in a dazed state for some time so that he was invariably late fo school. At 14 he became an apprentice toolmaker and was in frequent difficulty, sleeping so long some dayš that he missed work altogether. At the same age he tool? up amateur boxing, but despite good natural ability hơ became exhausted after one round and thereafter could do little more than defend himself. He found training excessively fatiguing and at the age of 19 he had to give up boxing. (Levin, 1959, described the case of a boxer being unable to continue boxing on account of narco? lepsy, and suggested that cataplexy occurs in the wakeof an undisguised or symbolic aggressive impulse.)

At 18, because his work record was so poor, he left tợl $1=$ making and joined the Army. During two years in Army symptoms increased, but the nature of the condition remained unrecognized. He was frequently in trouble for falling asleep during Army duties. Before entering the Army he had frequently experienced "cata-s plexie du reveil", but now cataplectic attacks during the day became an additional feature. These attacks were of the spontaneous variety and he does not recall that they were provoked by emotion. They took the form of $\Rightarrow$ momentary feelings of weakness with inability to speak or move. Attacks of this type occurred frequently during Army service, but since he left the Army have gradually? lessened in frequency and had not occurred recently.

After two years he was given a normal discharge and attempted a return to toolmaking, but again failed to adapt himself. From then onwards his work record wasdismal, and he attempted a wide range of jobs, including those of production engineering, car assembly, coali heaving, builder's labourer, painter, scrap merchant, $\frac{\mathrm{g}}{3}$ and door-to-door canvasser. Some jobs he gave up because he felt bored or exhausted; in others he fello asleep at the job and was sacked. A number of employers $>$ mistook his illness for epilepsy and he was dismissed.

Only at the age of 23 was his illness diagnosed by a neurologist, and he was treated with amphetamine. This. caused a lessening in the number of attacks but no N improvement in work record.

He married at 25 and when seen had a 7-month-old son. His marriage was happy apart from the anxiety created through his failure to keep in employment, and 
his wife's worry over his frequent nightmares from which he would awaken, screaming and shouting. On admission he was on $50 \mathrm{mg}$. dextro-amphetamine daily, but despite this was having daily attacks of narcolepsy, and nightmares every night.

There were no abnormal findings on physical and routine blood examinations, and skull radiographs were entirely negative.

Under observation as an in-patient he did not reveal overt neurotic traits, and psychiatric investigations showed no definite neurotic symptoms.

Twin Brother.- J. developed symptoms at 13, a few months later than his brother. He, too, experienced difficulty in morning waking and a tendency to fall asleep in a stuffy classroom. He left school at 14, and with his brother began work as an apprentice toolmaker. Although he had difficulty in getting to work in time, his symptoms were never as severe as those of his brother, and he was able to adapt better to working conditions. His record as an apprentice, although not perfect, was acceptable to his employers.

Like his brother he began amateur boxing, but gave up after 15 months on the pretext of a nose injury. He did not, however, suffer from the same fatigueability in the ring, but was more than ordinarily exhausted by training.

At $\mathbf{2 0}$ he joined the Army, and for two years of military service symptoms were much worse. He was often in trouble for falling asleep in the classroom, and his only attacks of cataplexy occurred in this period. One night, sleeping in a makeshift bed, he remembers vividly waking three times during the night, on each occasion terrified, but quite unable to shout or move. He had another attack of cataplexy while on guard duty. On this occasion he suddenly felt weak, unable to move or speak, and he thinks this lasted several seconds. He does not recall that this attack was precipitated by any emotion, and the attack appears to have been spontaneous.

On leaving the Army he returned to toolmaking with his former employer and since then has been symptomfree, excepting for frequent vivid nightmares. He has never received treatment for his narcolepsy. $\mathrm{He}$ is happily married, and now considers himself a normal, average person.

\section{Psychological Comparisons}

On the Bellevue oral scale, W., the patient, had a somewhat higher I.Q. than his brother (117 as against 111). This was accounted for by higher scores on digit span and on similarities.

On the Rorschach test, W. was more productive with 36 responses as against 28 . Only two responses coincided. J. showed some stereotypy and a rather narrower range of ideas with very little interest in colour. W. brought colour more into his responses and had nearly three times as many responses to the last three (coloured) cards. Of the two Rorschach protocols, W's showed rather less pathology.

\section{Electroencephalographic Comparisons}

Recordings were made and repeated on both patients. The records showed the basic similarity expected in identical twins. Episodic theta activity was seen in both records, slightly increased after overbreathing, and more marked in $W$. The records were extremely alike except that W. had more slow activity and slightly slower slow.

The theta was typical of the changes found in drowsiness, or drifting. Daly and Yoss (1957) have given a very clear account of such changes. They consider that the E.E.G. is within normal limits in narcolepsy, but shows repeated changes due to drowsiness. The records of the twins were in accordance with this view.

\section{Discussion}

The existence of a possible hereditary factor in idiopathic narcolepsy gained prominence when Krabbe and Magnussen (1942) reviewed all the cases in the literature and found that 54 of the cases belonged to 19 families, with from two to eight narcoleptics in each family. They postulated that inheritance is linked to a single dominant gene with relatively slight penetrative power.

This theory has been supported by a more recent report by Daly and Yoss (1959) on a family with narcolepsy. Investigations of this family disclosed a total of 12 instances of narcolepsy in three generations. The third generation contained one set of monozygotic twins, neither of whom were, however, afflicted with narcolepsy. Daly and Yoss suggest that the disorder in this family was transmitted by a single dominant factor with a high degree of penetrance. Daly (personal communication) has seen several instances of dizygotic twins in which only one was afflicted by narcolepsy, but has not observed narcolepsy in any monozygotic twins.

The case described here appears to be the first recorded one of its kind, and lends support to the idea of a genetic transmission of idiopathic narcolepsy. The basic difference that existed, in severity of affliction, between the twins did not seem sufficient to explain the whole difference in outcome. Psychological factors appear to have had a modifying effect on the course. Two factors may have been of importance. W. appeared to be more adventurous, more extrovert, with more drive, and with a wider range of interests. He was thus more easily bored by routine and unimaginative work. In addition, it was shown at occupational therapy, and confirmed at an industrial rehabilitation unit, that he had poor manual dexterity to such a degree that work with his hands must have given very little satisfaction; this may have contributed to his earlier failure to become a toolmaker like his brother.

It is satisfactory to conclude by recording that W. is now employed as a milk roundsman, and, despite reduction of dextro-amphetamine to $25 \mathrm{mg}$. daily, he seldom falls asleep during the day, and has very few nightmares. 


\section{Summary}

Case reports are presented on a set of identical twin brothers with idiopathic narcolepsy.

Psychological and electroencephalographic comparisons are shown.

Genetic implications and psychological differences are discussed.

I wish to acknowledge the cooperation of Dr. $\mathrm{H}$. Halstead, senior clinical psychologist at Uffculme Clinic, who carried out the psychological tests, interpreted the results, and acted as vocational adviser; also the cooperation of Dr. P. M. Jeavons, consultant psychiatrist at All Saints Hospital, Birmingham, who arranged the E.E.G. recordings, interpreted the records, and provided the opinion expressed on these records.

I would also like to thank Dr. J. J. O'Reilly, Medicalo

Director of Uffculme Clinic, for permission to publish ${ }_{\mathcal{C}}^{\nabla}$ this case.

\section{REFERENCES} Daly, D. D., and Yoss, R. E. (1957). Electroenceph. clin. Neuro

- (1959). Proc. Mayo Clin., 34, 313.

Krabbe, E., and Magnussen, G. (1942). Acta psychiat. (Kbh.), 17,

Levin, M. (1959), Amer. J. Psychiat., 116, 133.

Stern, C. (1950). Principles of Human Genetics, pp. 468-471. Freeman, San Francisco. 